\title{
Building Blocks for Self-Assembled Porphyrinc Photonic Wires
}

\author{
M. Koepf, ${ }^{\ddagger}$ A. Trabolsi, ${ }^{\dagger}$ M. Elhabiri, ${ }^{\dagger}$ J. A. Wytko, ${ }^{\ddagger \star}$ D. Paul, ${ }^{\ddagger}$ A. M. \\ Albrecht-Gary, ${ }^{\dagger *}$ and J. Weiss ${ }^{\ddagger *}$ \\ Laboratoire de Physico-Chimie Bioinorganique, UMR 7509 du CNRS, ECPM, \\ Université Louis Pasteur, 25 rue Becquerel, 67200 Strasbourg, France and \\ Laboratoire de Chimie des Ligands à Architecture Contrôlée, Institut de \\ Chimie, Université Louis Pasteur, 4, rue Blaise Pascal, 67070 Strasbourg, \\ France.
}

\section{Supporting Information}

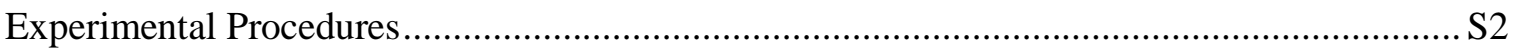

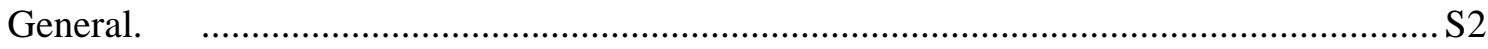

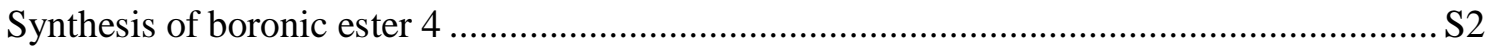

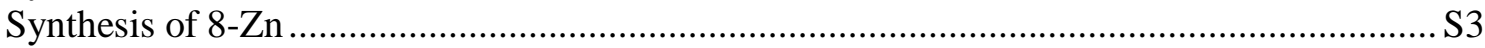

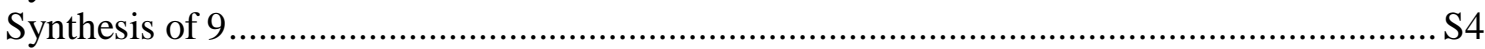

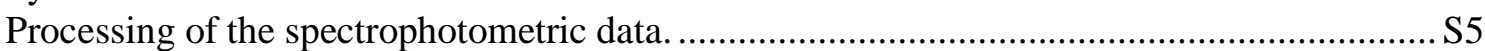

Figure S1. UV-visible absorption spectrophotometric titration of 8-Zn receptor with 9...... S6

Figure S2. UV-visible absorption spectrophotometric titration of 8-Zn receptor with 10 .... S7

Figure S3. UV-visible absorption spectrophotometric titration of 8-Zn receptor with $1-H$ imidazole (denoted Im).

Figure S4. Comparison of the electronic absorption spectrum of the triad 8-Zn-9 and the sum of the electronic spectra of 8-Zn-Im and 9

Figure S5. Comparison of the electronic absorption spectrum of the triad 8-Zn-10 and the sum of the electronic spectra of 8-Zn-Im and 10....................................... S10

Figure S6. Overlaps between the emission spectrum of ZnP-Im and the absorption of the

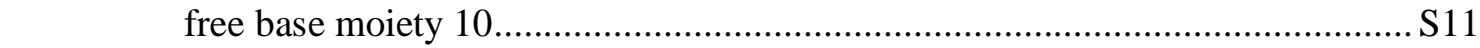

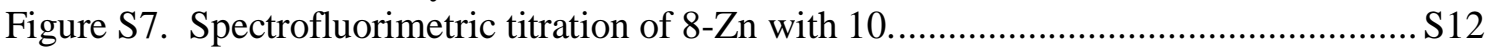

Figure S8. Spectrofluorimetric titration of 8-Zn with $1 H$-imidazole (denoted $\mathrm{Im}$ )............. S13

Figure S9. Normalized relative fluorescence spectra of 8-Zn-Im and 8-Zn-10 ................. S14

Figure $S 10$. Luminescence titration $\left(\mathrm{F}_{0} / \mathrm{F}\right)$ of 9-phenyl-borondipyrrin with 9.................. S15

Figure $S 11$. Luminescence titration $\left(\mathrm{F}_{0} / \mathrm{F}\right)$ of 9-phenyl-borondipyrrin with $10 \ldots \ldots \ldots \ldots \ldots . . . . . . . . . . . .616$

Figure S12. Electronic spectra of 8-Zn (black), 9 (red) and 10 (blue)............................. S17

Figure S13. $300 \mathrm{MHz}{ }^{1} \mathrm{H}$ NMR spectra of triad 8-Zn-10 and its components 8-Zn and 10 in

$\mathrm{CDCl}_{3}$. S18 


\section{Experimental Procedures}

\section{General.}

Compounds 1 and 5 were prepared according to references 1 and 2, respectively. Reagents and solvents of reagent-grade were purchased and used without further purification. $\mathrm{Et}_{2} \mathrm{O}$ was distilled over sodium/benzophenone under argon. $\mathrm{NEt}_{3}$ was distilled under argon over $\mathrm{KOH}$ prior to use. Anhydrous $\mathrm{Na}_{2} \mathrm{SO}_{4}$ was used as a drying agent after aqueous workup. Evaporation and concentration in vacuo were carried out at $\mathrm{H}_{2} \mathrm{O}$-aspirator pressure. Column chromatography was performed with alumina or silica gel from Merck (aluminium oxyde 90 standardized, activity II-III according to Brockmann; silica gel 60, 0.063-0.200 mm). Mass spectra were performed by le Service de Spectrométrie de Masse de l'Institut de Chimie, Université Louis Pasteur. Elemental analyses were performed by le Service d'Analyse Elementaire de l'Institut Universitaire de Technologie, Strasbourg, Sud. ${ }^{1} \mathrm{H}$ NMR spectra were recorded on an Bruker Advance 300 spectrometer (300 MHz).

\section{Synthesis of boronic ester 4}

To a solution of pinacolborane ${ }^{1} \mathbf{1}(200 \mathrm{mg}, 0.86 \mathrm{mmol})$ and 2,4-dimethyl-3ethylpyrrole $(276 \mu \mathrm{L}, 2 \mathrm{mmol})$ in Ar flushed $\mathrm{CH}_{2} \mathrm{Cl}_{2}(50 \mathrm{~mL})$, was added trifluoroacetic acid $(6 \mu \mathrm{L}, 84 \mu \mathrm{mol})$. After stirring the mixture for 3 hours at room temperature under Ar and in the dark, 2,3-dicyano-5,6-dichloroquinone (200 mg, $0.88 \mathrm{mmol})$ was added. The solution immediately turned dark violet and was stirred for $30 \mathrm{~min}$ at room temperature under Ar. Freshly distilled triethylamine $(3 \mathrm{~mL})$ was introduced, followed by $\mathrm{BF}_{3} \cdot \mathrm{Et}_{2} \mathrm{O}$ until green reflects appeared in the solution $(\sim 2 \mathrm{~mL})$. The mixture was washed with water $(3 \mathrm{x} 100 \mathrm{~mL})$, dried over $\mathrm{Na}_{2} \mathrm{SO}_{4}$, filtered, and evaporated to afford a dark oil. The latter was purified by silica gel chromatography $\left(\mathrm{CH}_{2} \mathrm{Cl}_{2} / \mathrm{C}_{6} \mathrm{H}_{12} 1 / 1\right)$ to yield $208 \mathrm{mg}(0.41 \mathrm{mmol}, 48 \%)$ of $\mathbf{3}$ as a green-brown solid (third eluted product). ${ }^{1} \mathrm{H} \mathrm{NMR}\left(\mathrm{CDCl}_{3}\right)$ : $7.89(\mathrm{~d}, \mathrm{~J}=8.2 \mathrm{~Hz}, 2 \mathrm{H}) ; 7.29$ (d, $\mathrm{J}=8.2 \mathrm{~Hz}, 2 \mathrm{H}) ; 2.85(\mathrm{q}, \mathrm{J}=7.5 \mathrm{~Hz}, 4 \mathrm{H}) ; 2.52(\mathrm{~s}, 6 \mathrm{H}) ; 1.39(\mathrm{~s}, 12 \mathrm{H}) ; 1.26(\mathrm{~s}, 6 \mathrm{H}) ; 0.97$ (t, J = $7.5 \mathrm{~Hz}, 6 \mathrm{H})$. MALDI-TOF MS: mass calculated for $\mathrm{M}+\mathrm{H}^{+}$: 507.32; found: 507.36.

Just prior to use in the next step, pinacolborane 3 (120 $\mathrm{mg}, 0.24 \mathrm{mmol})$ was dissolved in THF $(15 \mathrm{~mL})$, then $1 \mathrm{M} \mathrm{HCl}(5 \mathrm{~mL})$ was added. After stirring the mixture for 1 hour in the absence of light, diethylether (100 mL, non distilled) was added, and the organic layer was

\footnotetext{
${ }^{1}$ Yu, L; Lindsey, J. S.; Tetrahedron 2001, 57, 9285-9298
} 
washed with water $(5 \times 100 \mathrm{~mL})$. Solvents were evaporated and the residue was dried by azeotrope distillation with toluene to yield 4 as a greenish solid $(80 \mathrm{mg}$ ) as an impure compound that was used without purification for the subsequent step. It should be noted that this compound was sparingly soluble in most solvents.

\section{Synthesis of 4-(SEM-imidazole)-phenylboronic acid 6}

To an argon flushed solution of $\mathbf{5}^{\mathbf{2}}(0.9 \mathrm{~g}, 2.4 \mathrm{mmol})$ in freshly distilled diethyl ether $(100 \mathrm{~mL})$ at $-78^{\circ} \mathrm{C}, t$-BuLi $(1.6 \mathrm{M}$ in hexane, $3.5 \mathrm{~mL}, 5.6 \mathrm{mmol})$ was added. The mixture was stirred for $45 \mathrm{~min}$ at $-78^{\circ} \mathrm{C}$ under Ar. Trimethylborate $(1.1 \mathrm{~mL}, 1 \mathrm{~g}, 9.6 \mathrm{mmol})$ was introduced and the mixture was stirred for another hour at $-78^{\circ} \mathrm{C}$, then allowed to warm to room temperature over 2 hours. The mixture was washed with water $(3 \times 100 \mathrm{~mL})$, then with $1 \mathrm{M} \mathrm{NaOH}_{(\mathrm{aq})}(2 \times 100 \mathrm{~mL})$. The basic aqueous phases were combined and carefully neutralized ( $\mathrm{pH}$ adjusted to 6.5-7). The precipitate was extracted with diethylether to afford 6 (488 mg, $1.43 \mathrm{mmol}, 60 \%$ ) as a beige powder. The product was used without further purification. ${ }^{1} \mathrm{H}$ NMR (acetone- $\left.\mathrm{d}_{6}\right): 7.82(\mathrm{~d}, \mathrm{~J}=8.3 \mathrm{~Hz}, 2 \mathrm{H}) ; 7.66(\mathrm{~d}, \mathrm{~J}=8.3 \mathrm{~Hz}, 2 \mathrm{H}) ; 7.64$ (s, 2H); 7.40 (s, 1H); 7.10 (s, 1H); 5.57 (s, 2H); 3.68 (t, J=6.6 Hz, 2H); 0,98 (t, J=6.6 Hz, 2H) ; $0.02(\mathrm{~s}, 9 \mathrm{H})$.

\section{Synthesis of 8-Zn}

Suzuki coupling reaction: To a suspension of 1-bromo-phenanthroline strapped porphyrin (100 mg, $0.12 \mathrm{mmol}$ ), crude boronic acid 4 (80 mg), and $\mathrm{K}_{2} \mathrm{CO}_{3}(200 \mathrm{mg}, 1.4 \mathrm{mmol})$ in toluene $(10 \mathrm{~mL})$, were added water $(0.8 \mathrm{~mL})$ and methanol $(0.8 \mathrm{~mL})$. The mixture was $\mathrm{Ar}$ flushed, then $\mathrm{Pd}\left(\mathrm{PPh}_{3}\right)_{4}(5 \mathrm{~mol} \%)$ was introduced. After degassing by bubbling the mixture with $\mathrm{Ar}$ for another $15 \mathrm{~min}$, the reaction mixture was stirred at $60^{\circ} \mathrm{C}$ for 6 hours under Ar. The organic phase was washed with saturated $\mathrm{NH}_{4} \mathrm{Cl}_{(\mathrm{aq})}(2 \times 50 \mathrm{~mL})$, and water $(2 \times 50 \mathrm{~mL})$, then dried over $\mathrm{Na}_{2} \mathrm{SO}_{4}$, filtered, and evaporated to dryness to afford a dark residue. Purification by column chromatography $\left(\mathrm{Al}_{2} \mathrm{O}_{3}, \mathrm{C}_{6} \mathrm{H}_{12} / \mathrm{CH}_{2} \mathrm{Cl}_{2}: 1 / 1\right)$ yielded $\mathbf{8}-\mathbf{H}_{2}(112 \mathrm{mg}$ $0.10 \mathrm{mmol}, 83 \%)$ as a blood-red solid (third eluted product). ${ }^{1} \mathrm{H} \mathrm{NMR}\left(\mathrm{CDCl}_{3}\right): 10.13$ (s, $1 \mathrm{H}) ; 9.29(\mathrm{~d}, \mathrm{~J}=4.6 \mathrm{~Hz}, 2 \mathrm{H}) ; 8.99(\mathrm{~d}, \mathrm{~J}=4.6 \mathrm{~Hz}, 2 \mathrm{H}) ; 8.74(\mathrm{~d}, \mathrm{~J}=4.8,2 \mathrm{H}) ; 8.72\left(\mathrm{dd}, \mathrm{J}_{1}=7.1 \mathrm{~Hz}\right.$, $\left.\mathrm{J}_{2}=1.1 \mathrm{~Hz}, 2 \mathrm{H}\right) ; 8.66(\mathrm{~m}, 1 \mathrm{H}) ; 8.65(\mathrm{~d}, \mathrm{~J}=4.8 \mathrm{~Hz}, 2 \mathrm{H}) ; 7.98(\mathrm{~d}, \mathrm{~J}=8.4 \mathrm{~Hz}, 2 \mathrm{H}) ; 7.96-7.83$ (m,

\footnotetext{
${ }^{2}$ Leray, I.; Valeur, B.; Paul D., Regnier, E.; Koepf, M.; Wytko, J. A.; Boudon, C.; J. Weiss, Photochem. Photobio. Sci. in press.
} 
7H); 7.61-7.58 (m, 1H); 7.54 (d, J=8.4 Hz, 2H); 7.51 (m, 1H); 7.50 (s, 2H); 6.77 (d, J=8.4 Hz, 4H); 6.52 (d, J=8.4 Hz, 2H); 2.59 (s, 6H); 2.40 (q, J=7.5 Hz, 4H); 1.76 (s, 6H); 1.06 (t, J=7.5 $\mathrm{Hz}, 6 \mathrm{H}) ;-2.66(\mathrm{~s}, 2 \mathrm{H})$

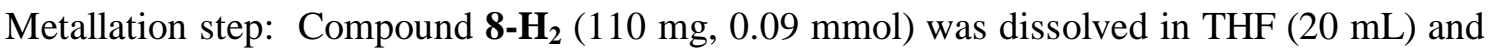
$\mathrm{Zn}(\mathrm{OAc})_{2}-2 \mathrm{H}_{2} \mathrm{O}(396 \mathrm{mg}, 1.8 \mathrm{mmol})$ was added. The mixture was stirred at $60^{\circ} \mathrm{C}$ for 4 hours, then poured into water. After filtration, the precipitate was dissolved in $\mathrm{CH}_{2} \mathrm{Cl}_{2}(80 \mathrm{~mL})$, washed with water $(3 \times 50 \mathrm{~mL})$, dried over $\mathrm{Na}_{2} \mathrm{SO}_{4}$, filtered, and evaporated in vacuo. Column chromatography purification $\left(\mathrm{Al}_{2} \mathrm{O}_{3}, \mathrm{CH}_{2} \mathrm{Cl}_{2}\right)$ yielded 8- $\mathbf{Z n}(97 \mathrm{mg}, 0.08 \mathrm{mmol}$, $87 \%)$ as a bright red solid (second eluted product). Mp. ${ }^{1} \mathrm{H}$ NMR $\left(\mathrm{CDCl}_{3}\right): 10.12(\mathrm{~s}, 1 \mathrm{H})$; 9.31 (d, J=4.6 Hz, 2H); 9.04 (d, J=4.6 Hz, 2H); 8.86 (d, J=4.6 Hz, 2H); 8.73 (d, J=4.8 Hz, $2 \mathrm{H}) ; 8.71(\mathrm{~d}, \mathrm{~J}=7.5 \mathrm{~Hz}, 2 \mathrm{H}) ; 8.54(\mathrm{~m}, 1 \mathrm{H}) ; 8.01(\mathrm{~m}, 1 \mathrm{H}) ; 7.97(\mathrm{~d}, \mathrm{~J}=8.4 \mathrm{~Hz}, 2 \mathrm{H}) ; 7.95-7.85$ (m, 6H); $7.57(\mathrm{~m}, 1 \mathrm{H}) ; 7.53-7.49(\mathrm{~m}, 5 \mathrm{H}) ; 6.67$ (d, J=8.4 Hz, 4H); 6.57 (d, J=8.4 Hz, 4H); $2.60(\mathrm{~s}, 6 \mathrm{H}) ; 2.41$ (q, J=7.5 Hz, 4H); 1.79 (s, 6H); 1.07 (t, J=7.5 Hz, 6H). MALDI-TOF MS: mass calculated for $\mathrm{M}+\mathrm{H}^{+}: 1231.41$; found: 1231.40 . E.A. calculated for $\mathrm{C}_{79} \mathrm{H}_{57} \mathrm{BF}_{2} \mathrm{~N}_{8} \mathrm{Zn}^{+}$ 1/3 $\mathrm{CHCl}_{3}+1 / 3$ THF: C 74.74, H 4.67, N 8.64; Found C 74.59, H 4.42, N 8.39. UV-vis in 1,2-dichloroethane, $\lambda_{\max }\left(\varepsilon\right.$ in $\left.\mathrm{M}^{-1} \mathrm{~cm}^{-1}\right)$ : $285 \mathrm{~nm}\left(6.9 \times 10^{4}\right) ; 312 \mathrm{~nm}\left(6.8 \times 10^{4}\right) ; 426 \mathrm{~nm}$ $\left(3.8 \times 10^{5}\right) ; 493 \mathrm{~nm}$ (shoulder); $525 \mathrm{~nm}\left(7.1 \times 10^{4}\right) ; 555 \mathrm{~nm}\left(2.0 \times 10^{4}\right) ; 596 \mathrm{~nm}\left(5.8 \times 10^{3}\right)$.

\section{Synthesis of 9}

Suzuki coupling reaction: This step was conducted using the same procedure as described for the synthesis of $\mathbf{8 - Z n}$, with the following reactants and solvents: 1-bromo-phenanthroline strapped porphyrin 7 (120 mg, $0.14 \mathrm{mmol})$, boronic acid 6 (100 mg, $0.30 \mathrm{mmol}), \mathrm{K}_{2} \mathrm{CO}_{3}(250$ $\mathrm{mg}, 1.8 \mathrm{mmol}$ ), $15 \mathrm{~mL}$ of toluene, $1 \mathrm{~mL}$ of water and $1 \mathrm{~mL}$ of methanol. Column chromatography purification $\left(\mathrm{Al}_{2} \mathrm{O}_{3}, \mathrm{C}_{6} \mathrm{H}_{12} / \mathrm{CH}_{2} \mathrm{Cl}_{2}\right.$ : 1/1) was conducted in the dark to yield SEM protected derivative of $9(117 \mathrm{mg}, 0.11 \mathrm{mmol}, 77 \%)$ as a violet solid (third eluated product). The compound was used without further purification for the deprotection step that follows. ${ }^{1} \mathrm{H}$ NMR $\left(\mathrm{CDCl}_{3}\right): 10.12(\mathrm{~s}, 1 \mathrm{H}) ; 9.27(\mathrm{~d}, \mathrm{~J}=4.6 \mathrm{~Hz}, 2 \mathrm{H}) ; 8.97(\mathrm{~d}, \mathrm{~J}=4.6 \mathrm{~Hz}, 2 \mathrm{H})$; 8.73-8.67 (m, 6H); 8.56-8.53 (m, 1H); $7.97(\mathrm{~d}, \mathrm{~J}=8.4 \mathrm{~Hz}, 2 \mathrm{H})$; 7.94-7.75 (m, 9H); 7.53 (d, $\mathrm{J}=8.2 \mathrm{~Hz}, 2 \mathrm{H}) ; 7.49$ (s, 2H); 7.20 (s, 1H); 7.16 (s, 1H); 6.76 (d, J=8.3 Hz, 4H); 6.49 (d, J=8.3 $\mathrm{Hz}, 4 \mathrm{H}) ; 5.55$ (s, 2H); 3.68 (t, J=7.7 Hz, 2H); 0.99 (t, J=7.8 Hz, 2H); -0.004 (s, 9H); -2.69 (s, 2H) 
Deprotection step: To a solution of SEM-protected $9(110 \mathrm{mg}, 0.07 \mathrm{mmol})$ in THF $(5 \mathrm{~mL})$, was added $1 \mathrm{M}$ TBAF (solution in THF, $0.5 \mathrm{~mL}, 0.5 \mathrm{mmol}$ ). The mixture was stirred at $50^{\circ} \mathrm{C}$ for 4 hours under Ar and in the dark, then poured into water. The precipitate was washed with water, redissolved in $\mathrm{CH}_{2} \mathrm{Cl}_{2}(50 \mathrm{~mL})$. The organic layer was again washed with water (3 x $50 \mathrm{~mL}$ ). Solvent was removed under vacuum and the residue was dried by azeotrope distillation with toluene. Column chromatography purification $\left(\mathrm{Al}_{2} \mathrm{O}_{3}, \mathrm{CH}_{2} \mathrm{Cl}_{2}\right.$, conducted in the dark) yielded 9 (40 mg, $0.04 \mathrm{mmol}, 60 \%)$ as a dark violet solid. Mp. $>350{ }^{\circ} \mathrm{C}{ }^{1} \mathrm{H} \mathrm{NMR}$ $\left(\mathrm{CDCl}_{3}\right): 10.12(\mathrm{~s}, 1 \mathrm{H}) ; 9.51(\mathrm{~m}, 1 \mathrm{H}) ; 9.27(\mathrm{~d}, \mathrm{~J}=4.6 \mathrm{~Hz}, 2 \mathrm{H}) ; 8.97(\mathrm{~s}, \mathrm{~J}=4.6 \mathrm{H}, 2 \mathrm{H}) ; 8.72-8.66$ (m, 5H); 8.51-8.48 (m, 1H); $7.98(\mathrm{~d}, \mathrm{~J}=8.4 \mathrm{~Hz}, 2 \mathrm{H}) ; 7.93-7.82(\mathrm{~m}, 8 \mathrm{H}) ; 7.53(\mathrm{~d}, \mathrm{~J}=8.4 \mathrm{~Hz}, 2 \mathrm{H})$; $7.50(\mathrm{~s}, 2 \mathrm{H}) ; 7.11(\mathrm{~s}, 2 \mathrm{H}) ; 6.91(\mathrm{~s}, 1 \mathrm{H}) ; 6.74(\mathrm{~d}, \mathrm{~J}=8.3 \mathrm{~Hz}, 4 \mathrm{H}) ; 6.49$ (d, J=8.3Hz, 4H); -2.72 (s, 2H). $\mathrm{FAB}^{+} \mathrm{MS}$ : mass calculated for $\mathrm{M}+\mathrm{H}^{+}$: 957.4 ; found: $957.3(100 \%)$. E.A. calculated for $\mathrm{C}_{67} \mathrm{H}_{40} \mathrm{~N}_{8}+2 / 3 \mathrm{CHCl}_{3}$ : C 78.40, H 3.95, N 10.81; Found C 78.33, H 3.87, N 10.58. UVVis in 1,2-dichloroethane, $\lambda_{\max }\left(\varepsilon\right.$ in $\left.\mathrm{M}^{-1} \mathrm{~cm}^{-1}\right): 286 \mathrm{~nm}\left(8.7 \times 10^{4}\right) ; 337 \mathrm{~nm}$ (shoulder); 421 $\mathrm{nm}\left(3.6 \times 10^{5}\right) ; 513 \mathrm{~nm}\left(1.5 \times 10^{4}\right) ; 548 \mathrm{~nm}\left(4.3 \times 10^{3}\right) ; 587 \mathrm{~nm}\left(4.6 \times 10^{3}\right) ; 643 \mathrm{~nm}(1.6 \times$ $\left.10^{3}\right)$.

\section{Processing of the spectrophotometric data.}

The spectrophotometric data were processed with both the Letagrop-Spefo and Specfit programs, which adjust the stability constants and the corresponding extinction coefficients of the species formed at equilibrium. Letagrop-Spefo ${ }^{3,5}$ uses the Newton-Raphson algorithm to solve mass balance equations and a pit-mapping method to minimize the errors and determine the best values of the parameters. Specfit ${ }^{6, \ldots 9}$ uses factor analysis to reduce the absorbance matrix and to extract the eigenvalues prior to the multi-wavelength fit of the reduced data set according to the Marquardt algorithm. ${ }^{10,11}$

3) Sillen, L. G. Acta Chem. Scand. 1964, 18, 1085-1098.

4) Sillen, L. G.; Warnqvist, B. Ark. Kemi. 1968, 31, 377-390.

5) Havel, J. Pure Appl. Chem. 1972, 34, 370-388.

6) Gampp, H.; Maeder, M.; Meyer, C. J.; Zuberbühler, A. D. Talanta 1985, 32, 95-101.

7) Rossoti, F. J. C.; Rossoti, H. S.; Whewell, R. J. J. Inorg. Nucl. Chem. 1971, 33, 2051-2065.

8) Gampp, H.; Maeder, M.; Meyer, C. J.; Zuberbühler, A. D. Talanta 1985, 32, 257-264.

9) Gampp, H.; Maeder, M.; Meyer, C. J.; Zuberbühler, A. D. Talanta 1986, 33, 943-951.

10) Marquardt, D. W. J. Soc. Indust. Appl. Math. 1963, 11, 431-441.

11) Maeder, M.; Zuberbühler, A. D. Anal. Chem. 1990, 62, 2220-2224. 

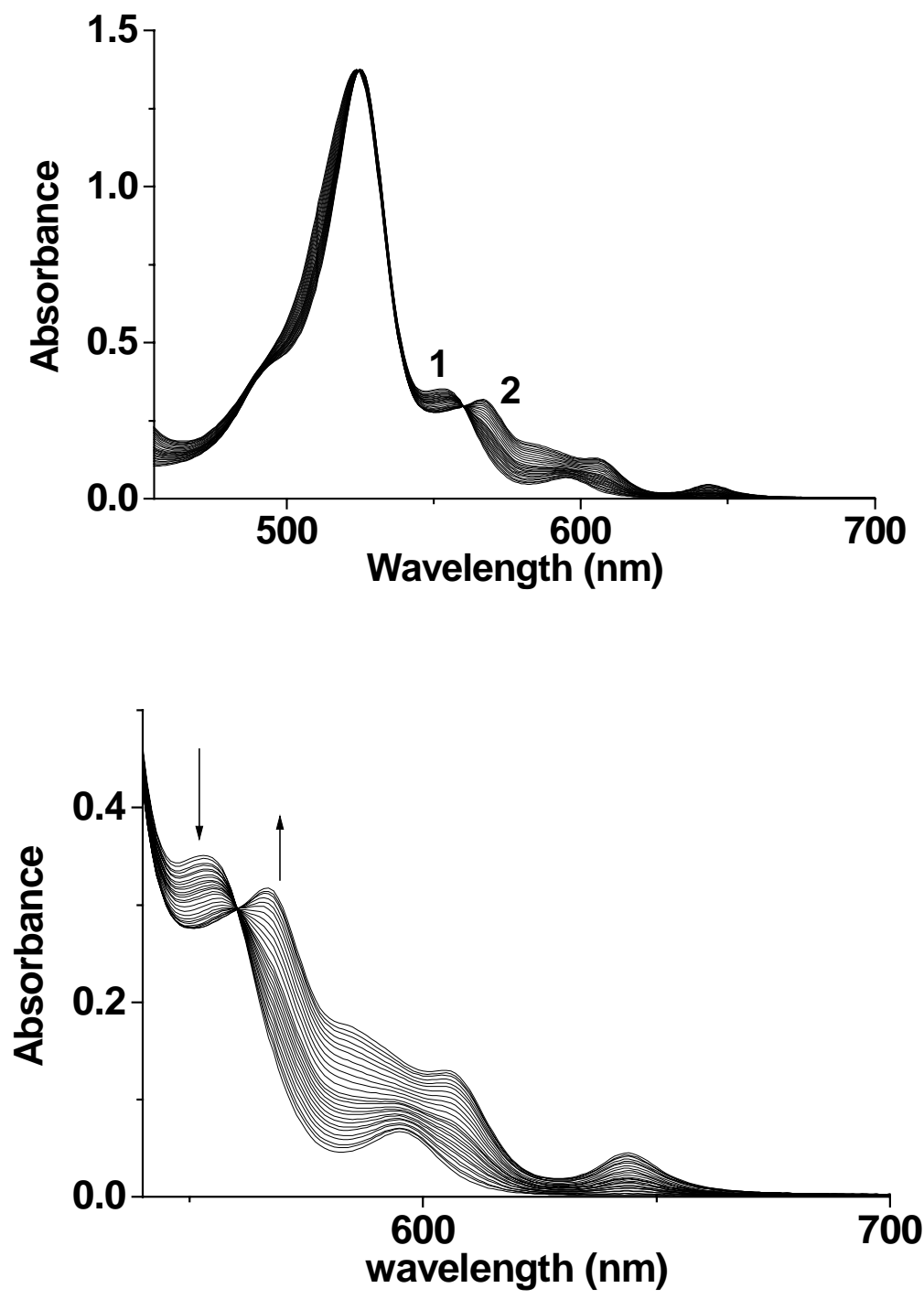

Figure S1. UV-visible absorption spectrophotometric titration of 8-Zn receptor with $\mathbf{9}$. Solvent: 1,2-dichloroethane; $T=25.0(2){ }^{\circ} \mathrm{C} ; l=1 \mathrm{~cm} ;(1)[\mathbf{8 - Z n}]_{\text {tot }}=2.00 \times$ $10^{-5} \mathrm{M}$; (2) $[\mathbf{9}]_{\text {tot }} /[\mathbf{8}-\mathbf{Z n}]_{\text {tot }}=1.32$. 

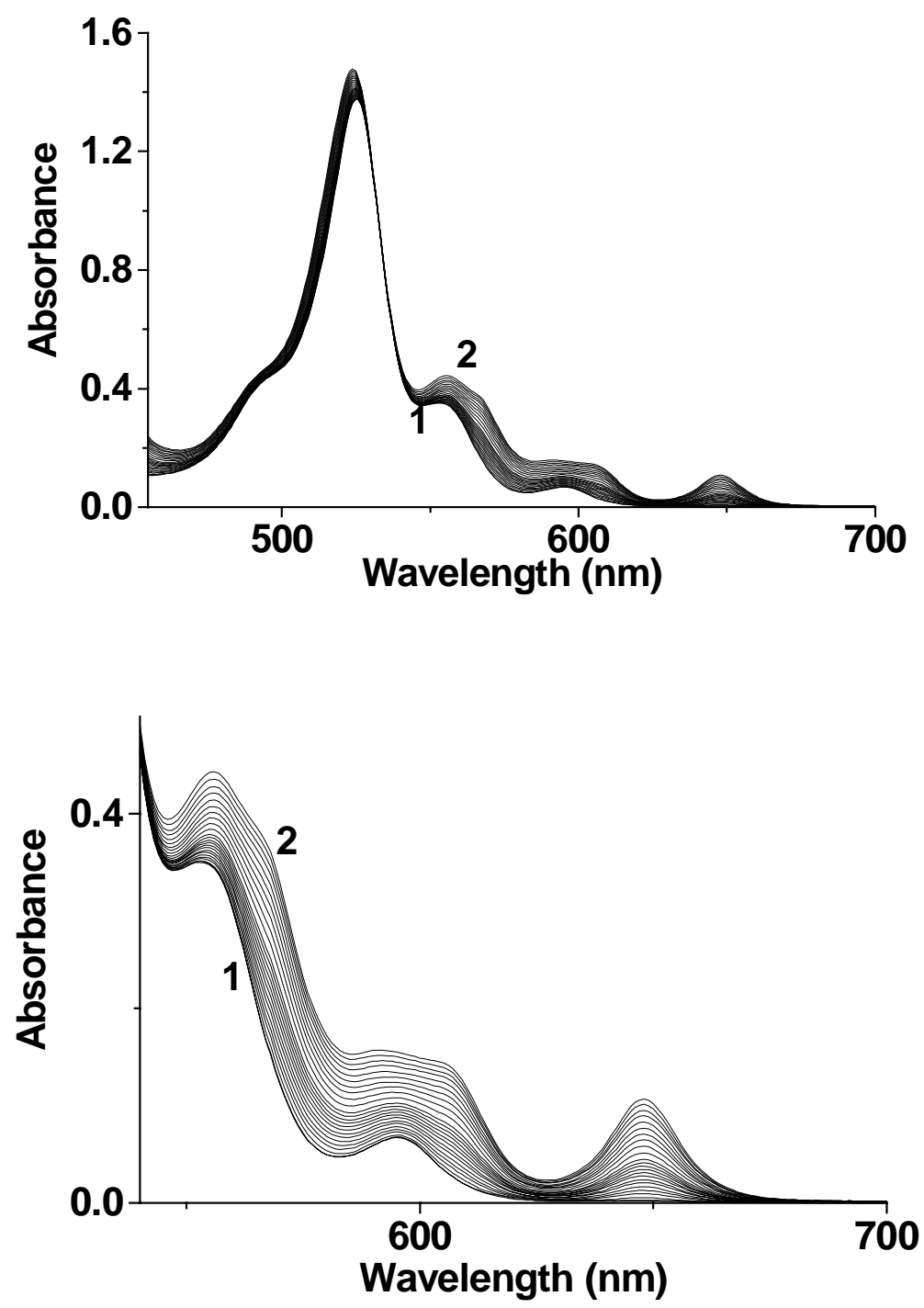

Figure S2. UV-visible absorption spectrophotometric titration of $\mathbf{8 - Z n}$ receptor with $\mathbf{1 0 .}$ Solvent: 1,2-dichloroethane; $\mathrm{T}=25.0(2){ }^{\circ} \mathrm{C} ; l=1 \mathrm{~cm} ;(1)[\mathbf{8 - Z n}]_{\mathrm{tot}}=2.00 \times$ $10^{-5} \mathrm{M} ;(2)[\mathbf{1 0}]_{\mathrm{tot}} /[\mathbf{8}-\mathbf{Z n}]_{\mathrm{tot}}=1.14$. 

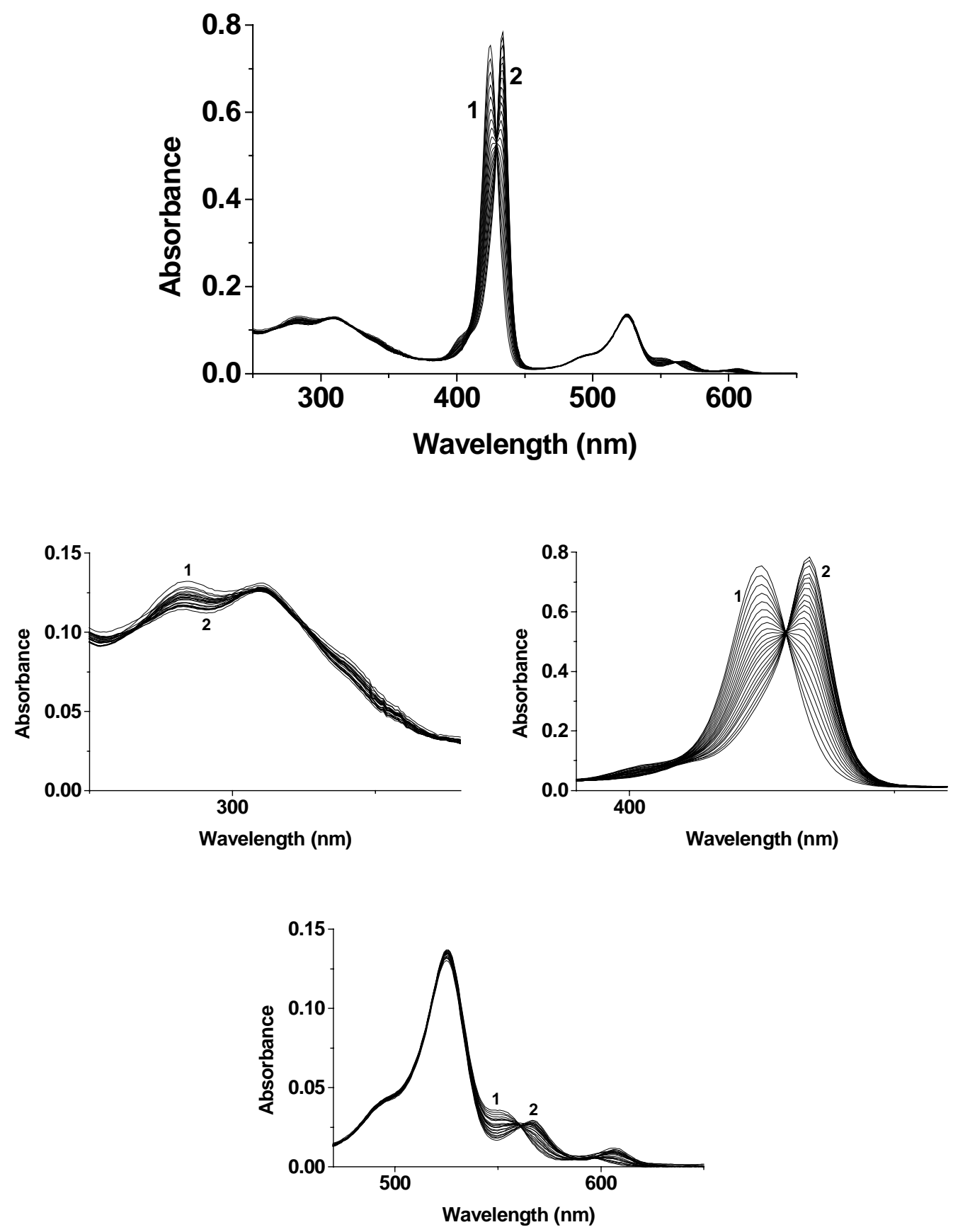

Figure S3. UV-visible absorption spectrophotometric titration of 8-Zn receptor with 1-Himidazole (denoted Im).

Solvent: 1,2-dichloroethane; $T=25.0(2){ }^{\circ} \mathrm{C} ; l=1 \mathrm{~cm} ;(1)[\mathbf{8 - Z n n}]_{\text {tot }}=2.01 \times$ $10^{-6} \mathrm{M} ;(2)[\mathbf{I m}]_{\mathrm{tot}} /[\mathbf{8}-\mathbf{Z n}]_{\mathrm{tot}}=2.0$. 


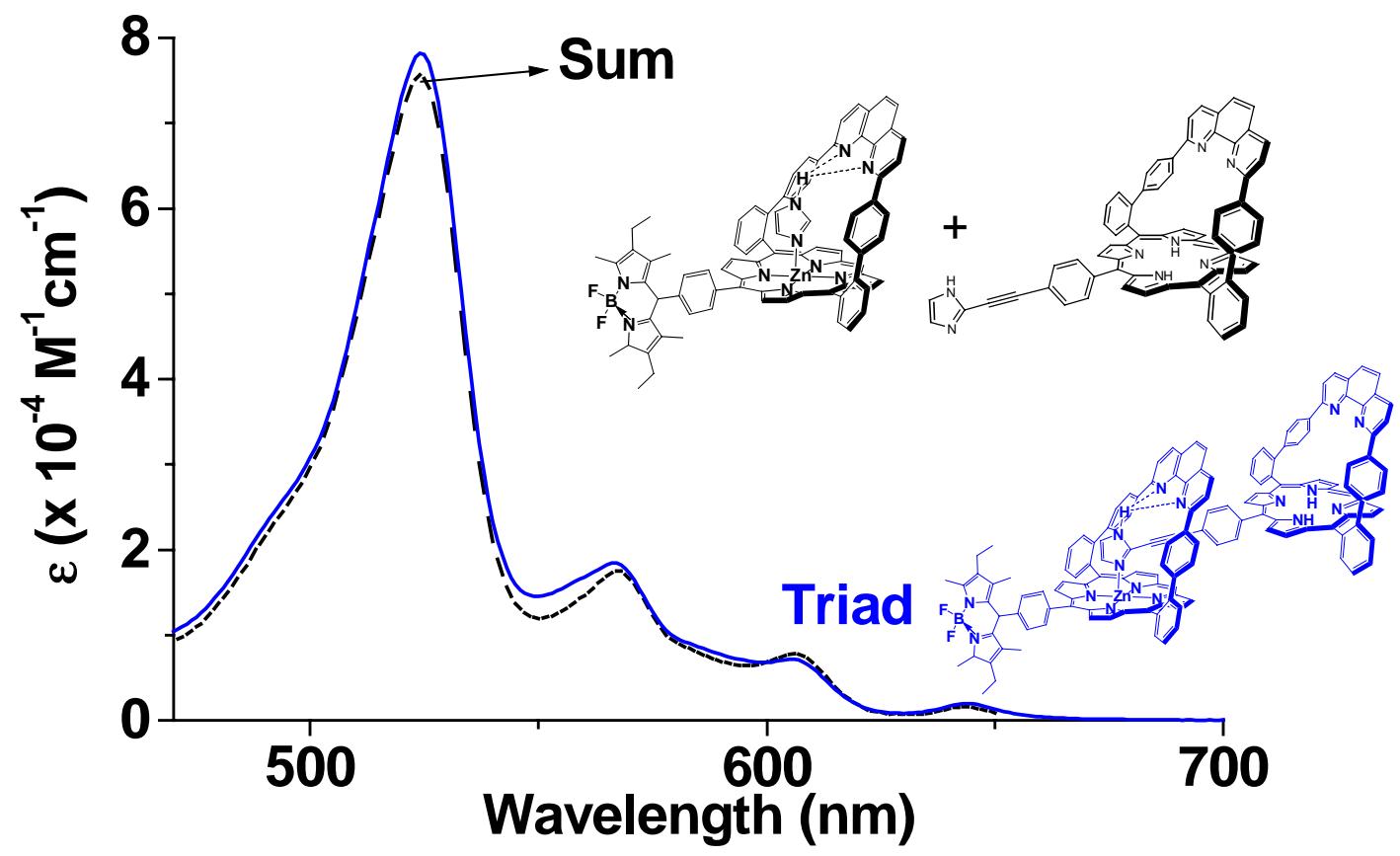

Figure S4. Comparison of the electronic absorption spectrum of the triad 8-Zn-9 (solid blue line) and the sum of the electronic spectra of 8-Zn-Im and $\mathbf{9}$ (dashed black line).

Solvent : 1,2-dichloroethane, $T=25.0(2){ }^{\circ} \mathrm{C}$. 


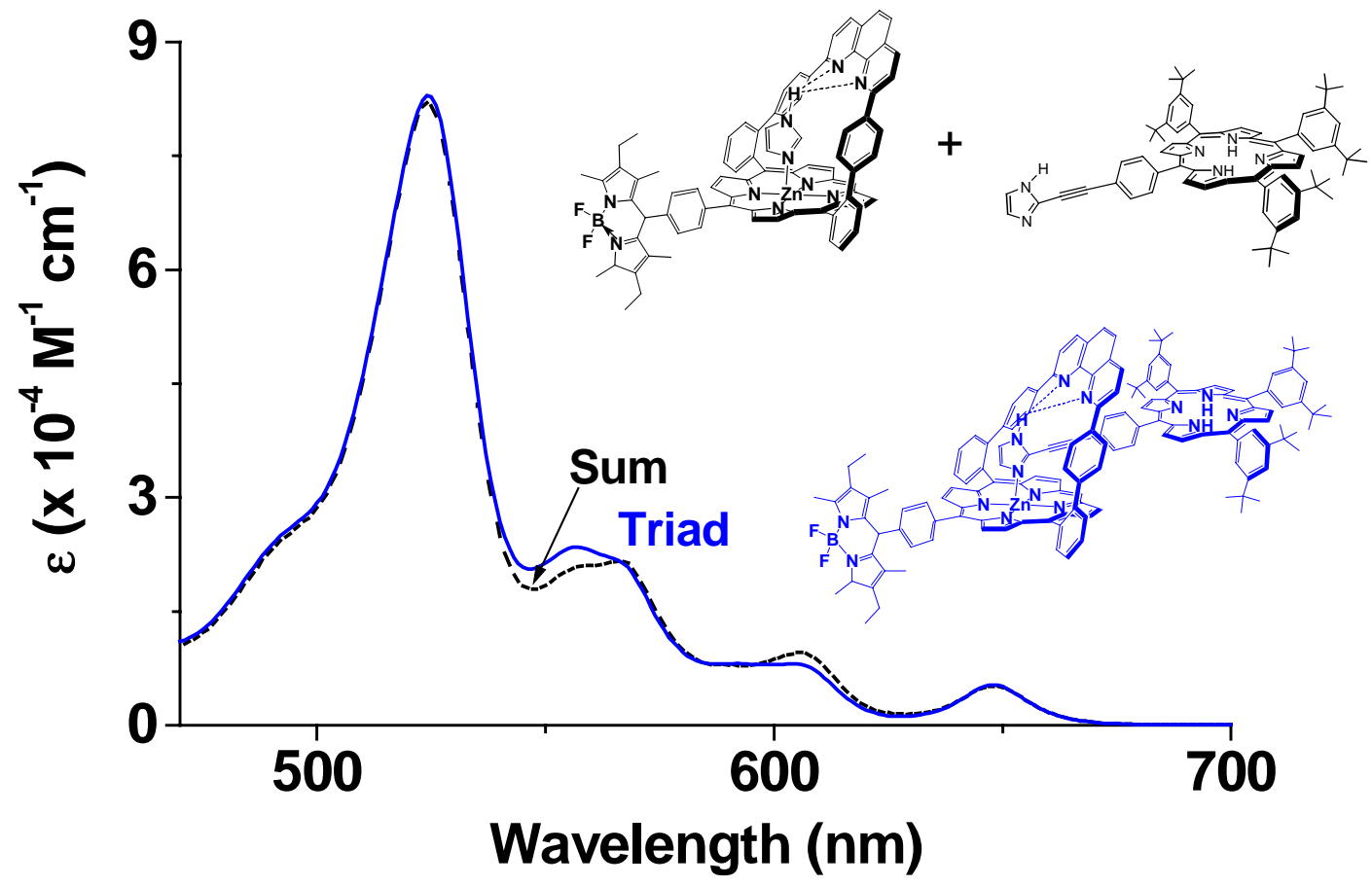

Figure S5. Comparison of the electronic absorption spectrum of the triad 8-Zn-10 (solid blue line) and the sum of the electronic spectra of 8-Zn-Im and $\mathbf{1 0}$ (dashed black line).

Solvent : 1,2-dichloroethane, $T=25.0(2){ }^{\circ} \mathrm{C}$. 


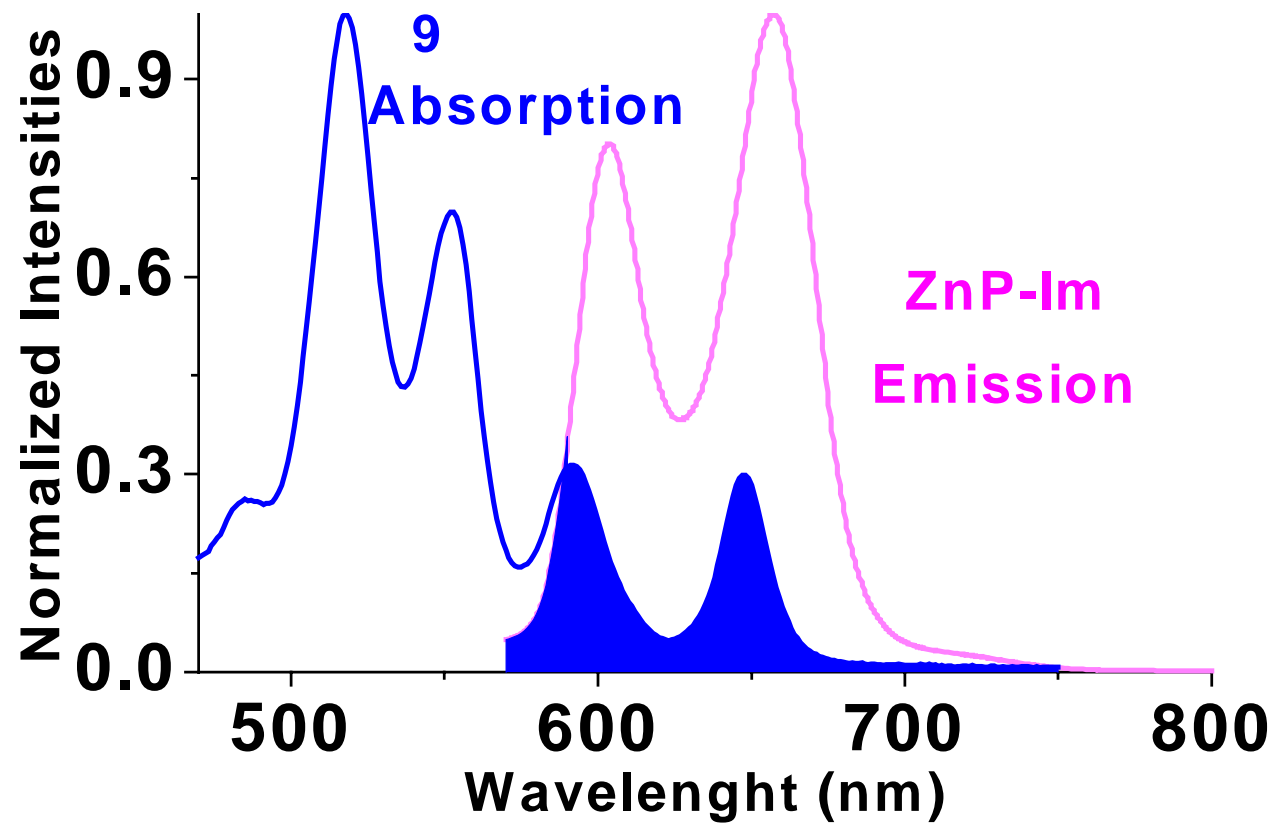

Figure S6. Overlaps between the emission spectrum of ZnP-Im and the absorption of the free base moiety $\mathbf{1 0}$ 


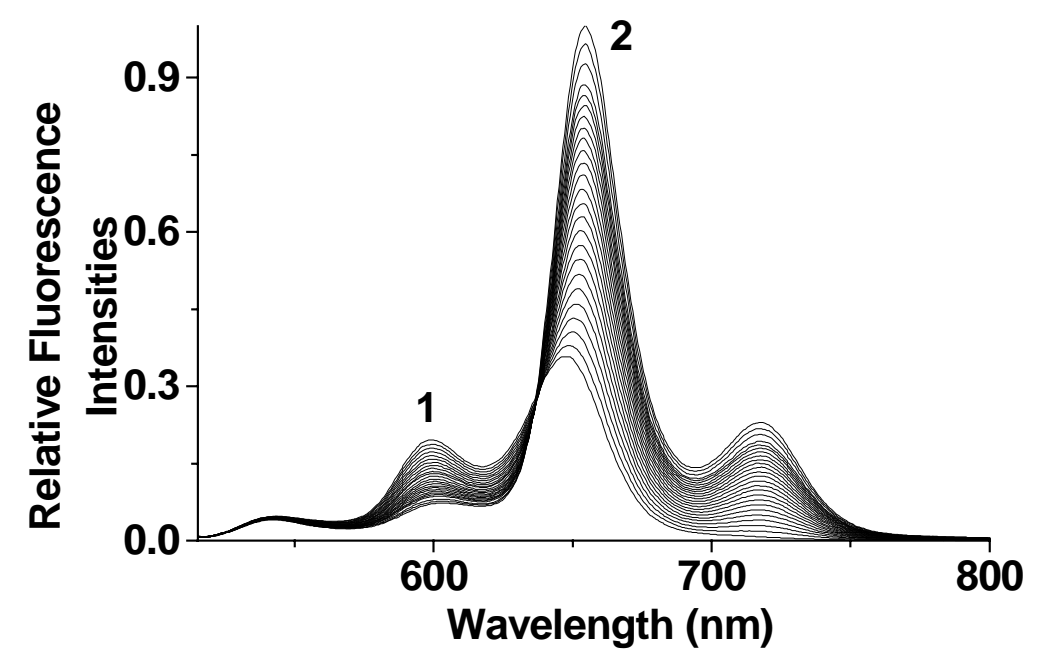

Figure S7. Spectrofluorimetric titration of 8-Zn with $\mathbf{1 0 .}$

Solvent: 1,2 -dichloroethane $\left(0.02 \%\right.$ by weight 2,6 -lutidine); $T=25.0(2){ }^{\circ} \mathrm{C}$; $\lambda_{\text {exc }}=495 \mathrm{~nm}\left({ }^{\downarrow}\right.$ BODIPY $) ;[8-Z n]_{\text {tot }}=5.02 \times 10^{-6} \mathrm{M} ;(1)[\mathbf{1 0}]_{\text {tot }} /[\mathbf{8}-\mathbf{Z n}]_{\text {tot }}=0$; (2) $[\mathbf{1 0}]_{\text {tot }} /[\mathbf{8}-\mathbf{Z n n}]_{\text {tot }}=1.38$. 


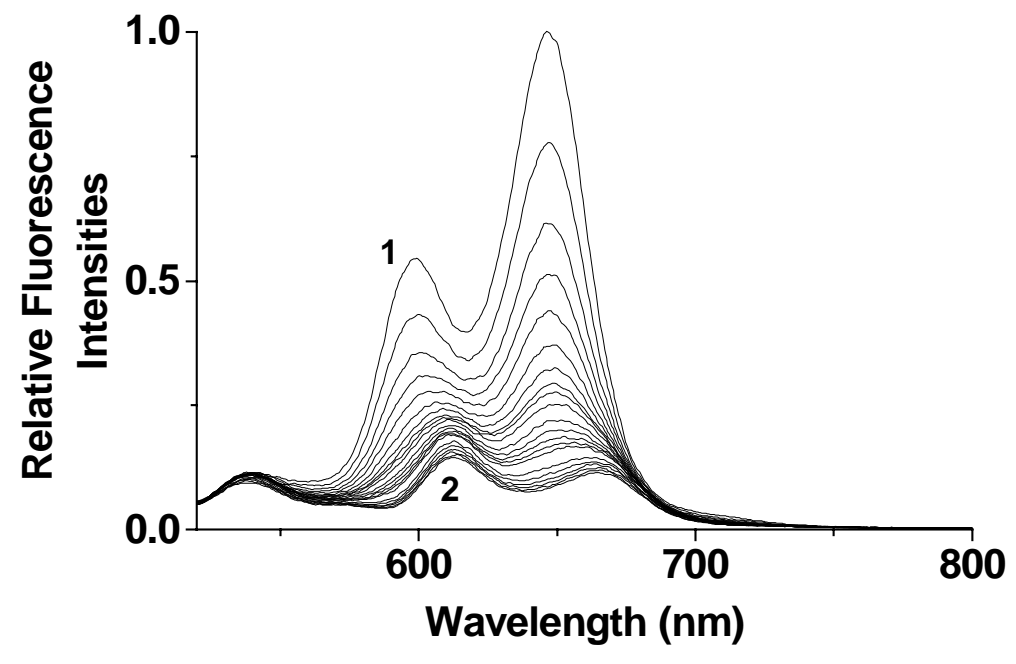

Figure S8. Spectrofluorimetric titration of 8-Zn with $1 H$-imidazole (denoted $\mathbf{I m}$ ).

Solvent: 1,2-dichloroethane; $T=25.0(2){ }^{\circ} \mathrm{C} ; \lambda_{\text {exc }}=495 \mathrm{~nm}\left({ }^{\downarrow}\right.$ BODIPY);

$[\mathbf{8 - Z n}]_{\mathrm{tot}}=1.00 \times 10^{-6} \mathrm{M}$; (1) $[\mathbf{I m}]_{\mathrm{tot}} /[\mathbf{8 - Z \mathbf { n }}]_{\mathrm{tot}}=0 ;(2)[\mathbf{I m}]_{\mathrm{tot}} /[\mathbf{8 - Z \mathbf { n n }}]_{\mathrm{tot}}=2.91$. 


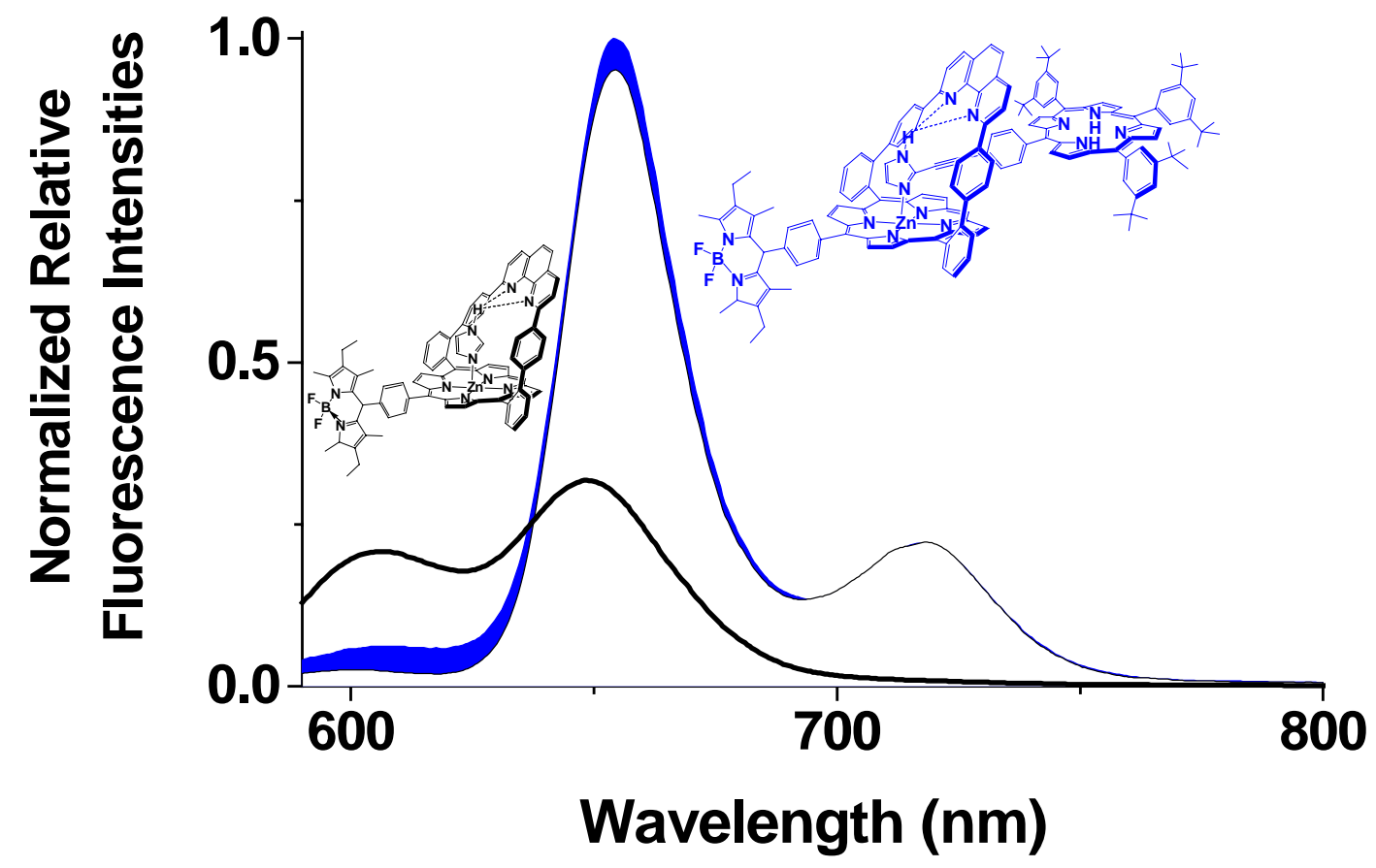

Figure S9. Normalized relative fluorescence spectra of 8-Zn-Im (black) and 8-Zn-10 (blue).

Solvent: 1,2 -dichloroethane $\left(0.02 \%\right.$ by weight 2,6 -lutidine); $T=25.0(2){ }^{\circ} \mathrm{C}$;

$\lambda_{\text {exc }}=560 \mathrm{~nm}$ ( ${ }^{\downarrow} \mathrm{Zn}$ unit). The area filled in blue corresponds to the non transmitted emission arising from the central zinc porphyrin in the triads. 


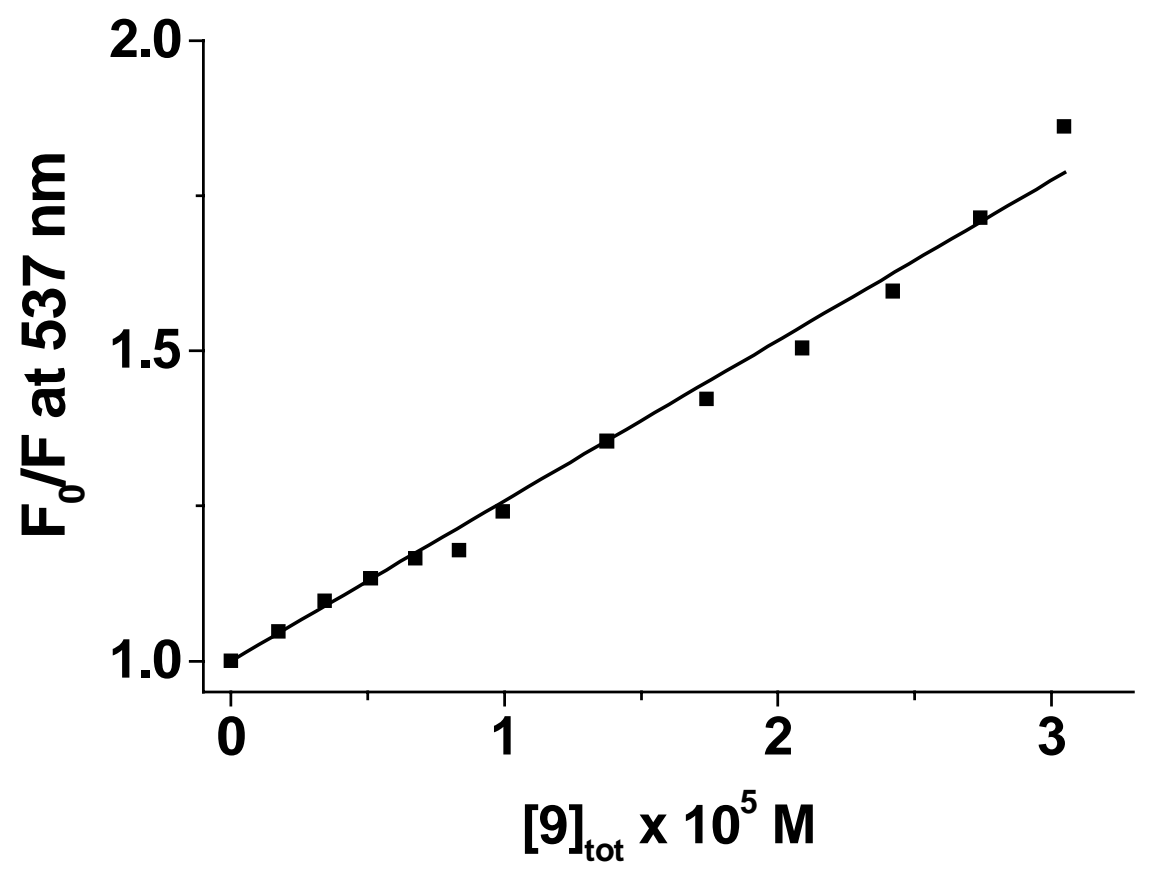

Figure S10. Luminescence titration $\left(\mathrm{F}_{0} / \mathrm{F}\right)$ of 9-phenyl-borondipyrrin with 9.

Solvent: 1,2 -dichloroethane $\left(0.02 \%\right.$ by weight 2,6 -lutidine); $T=25.0(2){ }^{\circ} \mathrm{C}$; $\lambda_{\text {exc }}=495 \mathrm{~nm}\left({ }^{\downarrow}\right.$ BODIPY $)$. [BODIPY $]_{\text {tot }}=2.29 \times 10^{-6} \mathrm{M}$. The full line corresponds to the linear least squared fit of experimental data according $\mathrm{F}_{0} / \mathrm{F}=1+K_{\mathrm{SV}}[9]_{\text {tot }}$. 


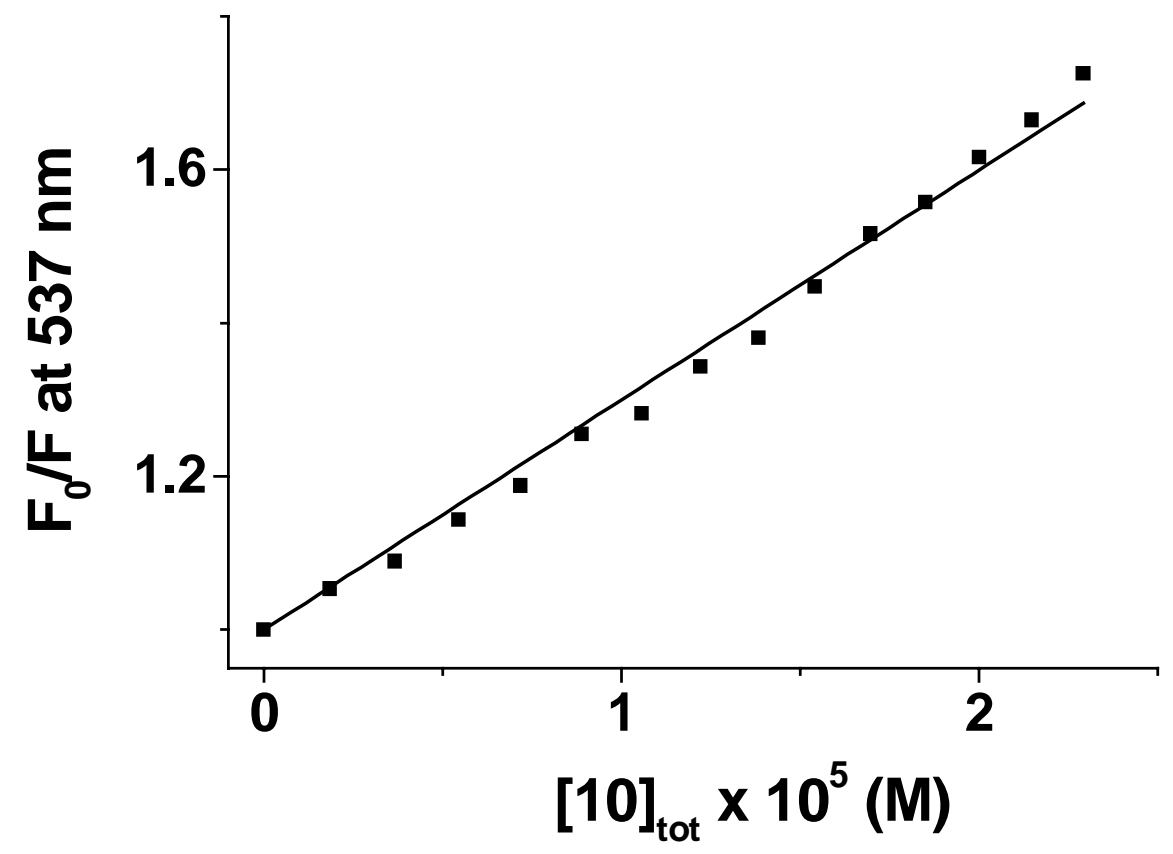

Figure S11. Luminescence titration $\left(\mathrm{F}_{0} / \mathrm{F}\right)$ of 9-phenyl-borondipyrrin with 10.

Solvent: 1,2 -dichloroethane $\left(0.02 \%\right.$ by weight 2,6 -lutidine); $T=25.0(2){ }^{\circ} \mathrm{C}$; $\lambda_{\text {exc }}=495 \mathrm{~nm}\left({ }^{\downarrow}\right.$ BODIPY $)$. [BODIPY $]_{\text {tot }}=2.29 \times 10^{-6} \mathrm{M}$. The full line corresponds to the linear least squared fit of experimental data according $\mathrm{F}_{0} / \mathrm{F}=1+K_{\mathrm{SV}}[\mathbf{1 0}]_{\text {tot }}$. 


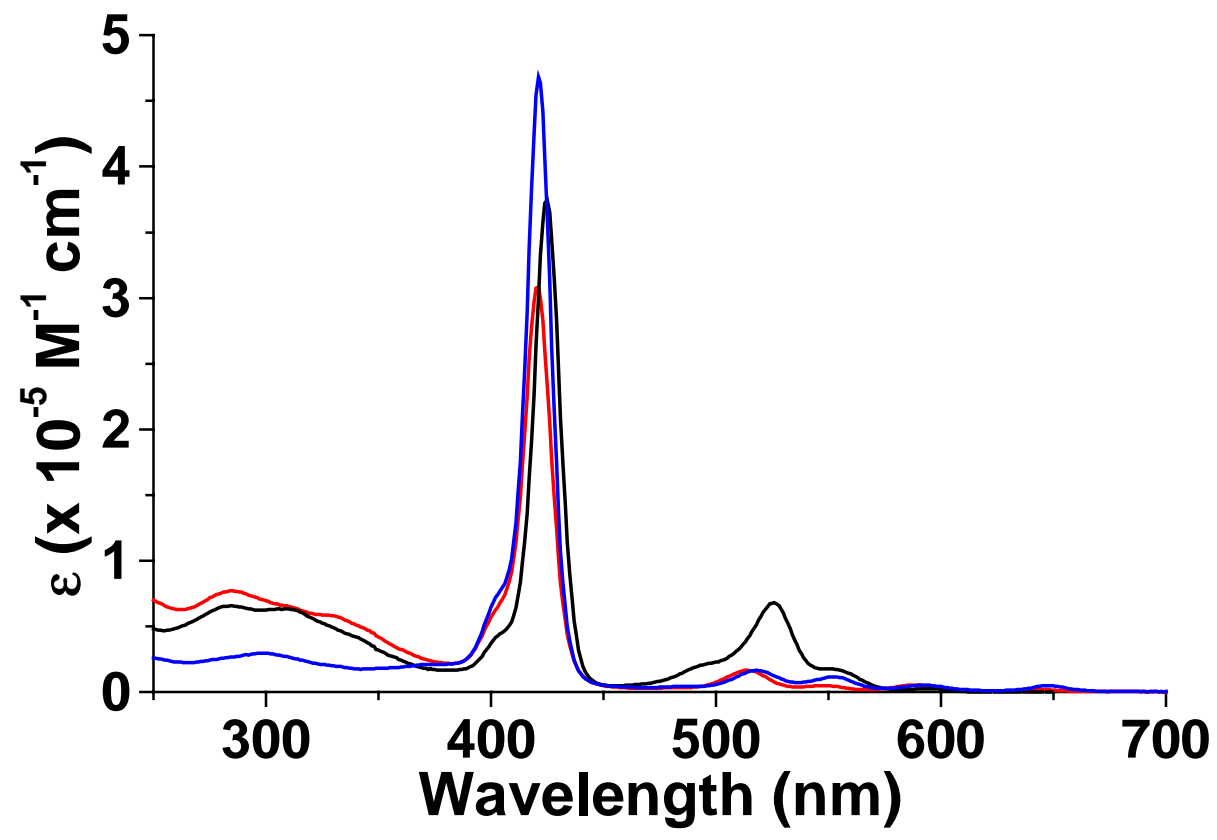

Figure S12. Electronic spectra of 8-Zn (black), 9 (red) and $\mathbf{1 0}$ (blue).

Solvent : 1,2-dichloroethane, $T=25.0(2){ }^{\circ} \mathrm{C}$. 


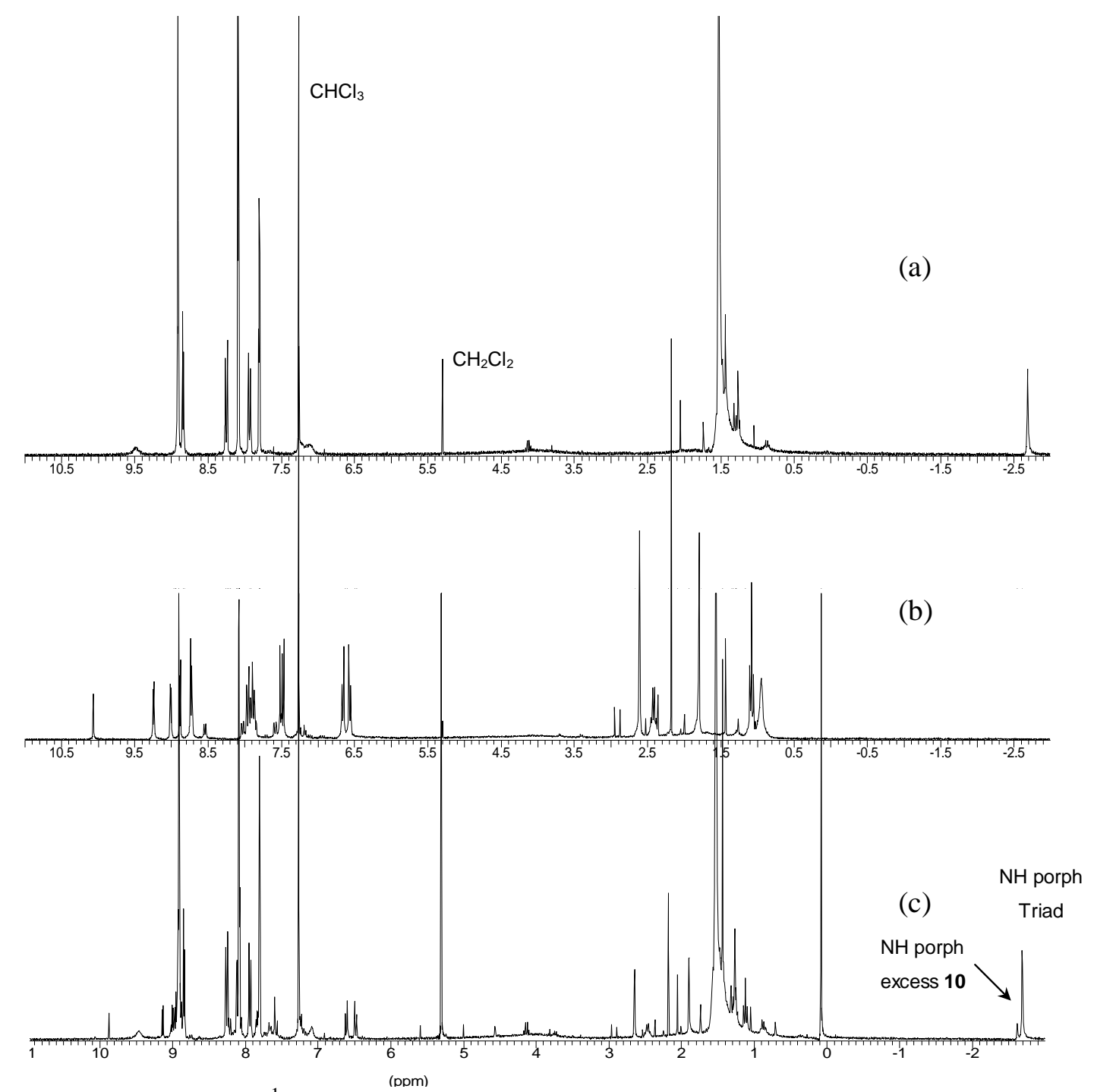

Figure S13. $300 \mathrm{MHz}{ }^{1} \mathrm{H}$ NMR spectra of triad 8-Zn-10 and its components $\mathbf{8 - Z n}$ and 10 in $\mathrm{CDCl}_{3}$.

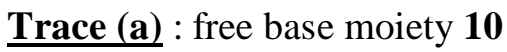

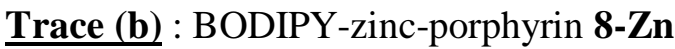

$\underline{\text { Trace }(\mathbf{c})}: \mathbf{8 - Z \mathbf { n }}+1.1$ equivalents of $\mathbf{1 0}$. Only two isomers are possible with the imidazole in the phenanthroline pocket, one in which the free base porphyrin will stand above the BODIPY unit, and one in which the free base porphyrin will be opposite to the BODIPY.

The simplicity of the overall spectrum, especially the presence of only one AX pattern at 6.5 ppm suggests the presence of only one geometrical isomer in solution. The fact that the BODIPY signals between 0.5 and 3 ppm do not show significant shielding confirms that this 
portion of the molecule is remote from the free base. Only a linear arrangement is observed, as depicted in the abstract figure. 